O. Nalapko ${ }^{1}$, R. Pikul ${ }^{2}$, P. Zhuk ${ }^{2}$, A. Shyshatskyi ${ }^{1}$

${ }^{1}$ Central Research Institute of Weapons and Military Equipment of Armed Forces of Ukraine, Kyiv, Ukraine

${ }^{2}$ National Defence University of Ukraine named after Ivan Chernyakhovsky, Kyiv, Ukraine

\title{
ANALYSIS OF MATHEMATICAL APPARATUS FOR MANAGING CHANNEL AND NETWORK RESOURCES OF MILITARY RADIO COMMUNICATION SYSTEMS
}

\begin{abstract}
The experience of carrying out the Operation of the United Nations (antiterrorist operation) on the territory of Donetsk and Luhansk oblasts shows that the existing procedure for managing the channel and network resources of military radiocommunication systems does not meet the modern requirements, which are put forward for them. The choice of a route in special purpose networks with the ability to self-organize on the basis of specific parameters is the main problem for managing the channel and network resources of special-purpose networks, as well as the difficult task of climbing the network. In this article, the authors analyzed the existing mathematical apparatus for controlling channel and network resources of military radiocommunication systems. During the research, the authors of the article used the classical methods of scientific knowledge, namely, the methods of analysis and synthesis, the basic provisions of the theory of communication, methods of modeling of communication networks, the theory of artificial intelligence, and others. It is established that the existing methods of controlling the channel and network resources of military radiocommunication systems take into account only certain factors influencing the quality of the use of channel and network resources of military radiocommunication systems. Therefore, it is the most expedient to choose a route for information transmission on many parameters based on fuzzy logic and a modified method of the ant colony system, through which searches and maintenance of the path of the packet passing between two points between the node from which the IP packet and the destination node are sent. To find a route, the following parameters must be considered: the energy component, the data rate, the time delay of the IP packet from the node that sends the packet to the destination node and the reliability of the delivery of the IP packet. These parameters should be taken into account while creating mathematical models, methods and techniques for managing channel and network resources of military radio communication systems.
\end{abstract}

Keywords: radio communication system, radio resource, channel and network resources, network topology, communication network, routing.

\section{Introduction}

In route selection tasks, as a rule, a couple of nodes, which sends an IP packet and an IP packet destination node, while there are many possible routes to select. The goal is to find the route with the lowest cost, based on the cost, calculated for different possible directions.

Some modern protocols for dynamic routing in special purpose networks have built-in algorithms for finding the route, which tries to minimize the cost of delivery of packets from the destination node to the destination node. However, the specifics of the use of special-purpose networks require the development of new routing methods and techniques, taking into account a plurality of parameters to ensure the delivery of data from the sending node to the destination node.

Finding the shortest path (less cost) between a pair of points is a complex problem, which requires a calculation of all possible routes. In addition, most users need not only routes with the least number of hopes to the destination but routes that can meet other important requirements. Such users most often need to provide support for the power component to increase battery life, to take into account the speed of the communication channel, the delay time for delivering the IP packet between the sender node and the destination node, and the reliability of the IP delivery of the package by the route.

Known scientific research does not take into account all these important parameters in one search and maintenance route in special purpose networks with the ability to self-organize. In turn, the system of ant colonies, combined with fuzzy logic, is used in the modified dynamic routing protocol (DSR) algorithm.
The purpose of this article is to make an analysis of the existing methods of controlling channel and network resources of military radio communication systems.

\section{Presentation of the main material}

One of the most significant limitations of fuzzy output systems is the difficulty of building a knowledge base with more than five factors under consideration, provided that more terms are used to describe the factor. The generalization of the analysis of information processing methods is presented in Table 1 .

Summarizing the analysis and taking into account the analysis of work on information processing [1-12] the most expedient is considered the choice of methods of the theory of fuzzy sets for the processing of factors and for the evaluation of information, since its application allows us to develop a mechanism for processing information, takes into account the mutual influence of verbally and numerically described factors, presented in various assessment scales.

Fuzzy logic and artificial neural networks. A fuzzy logic system is a popular and powerful tool that is being implemented by researchers for optimal route selection. Considering the problem of finding a route as a multi-criteria problem, [13] presents various approaches to optimize the search process and make decision choosing a route using fuzzy sets and fuzzy logic. The basis of fuzzy logic that was initiated by the American scientist Lotfi Zadeh $[10,11]$ allows us to describe qualitative inaccurate concepts and knowledge about the surrounding world. The methods of constructing information models based on this theory substantially expand the scope of application of information systems. 
Table 1 - Generalization of the analysis of information processing methods

\begin{tabular}{|l|l|l|}
\hline \multicolumn{1}{|c|}{ Method name } & \multicolumn{1}{|c|}{ Brief description } & \multicolumn{1}{c|}{ Limitations } \\
\hline Factor analysis & $\begin{array}{l}\text { Balance assessment of factor sets, score estimation of } \\
\text { sets of levels of factors values, the definition of a } \\
\text { general assessment taking into account the works of } \\
\text { factors on their significance level }\end{array}$ & $\begin{array}{l}\text { The need for experts to assess the factors and } \\
\text { levels of their significance, the complexity of } \\
\text { accounting factors that have a nonlinear impact } \\
\text { on the overall assessment, the complexity of } \\
\text { the processing of information in a verbal form }\end{array}$ \\
\hline Spectral analysis & $\begin{array}{l}\text { Representation of the initial value of the function of } \\
\text { the investigated process in the form of a set of } \\
\text { sinusoidal components, which allows to detect hidden } \\
\text { cycles in the development process }\end{array}$ & $\begin{array}{l}\text { The need a significant sample of values of } \\
\text { the process to build its graphical } \\
\text { dependence, the focus on the processing of } \\
\text { information presented in numerical form }\end{array}$ \\
\hline Neural networks & $\begin{array}{l}\text { Construction of a mechanism for determining the } \\
\text { output variable based on the input factors due to the } \\
\text { correction of the values of the synapse weights (edges) } \\
\text { of the network }\end{array}$ & $\begin{array}{l}\text { The complexity of verbally described } \\
\text { information processing, the secrecy of the } \\
\text { network learning process, the need for a } \\
\text { sufficient number of examples used for training } \\
\text { the network, making it difficult to adjust the } \\
\text { network during its operation }\end{array}$ \\
\hline Delphi method & $\begin{array}{l}\text { Obtaining a generalized assessment on the subject } \\
\text { under consideration by the expert group }\end{array}$ & $\begin{array}{l}\text { Dependence of the result on the opinion of } \\
\text { experts }\end{array}$ \\
\hline $\begin{array}{l}\text { The theory of fuzzy } \\
\text { sets }\end{array}$ & $\begin{array}{l}\text { Summarization of information provided in numerical } \\
\text { and verbal forms through the use of the representation } \\
\text { of input variables in the form of fuzzy numbers, with } \\
\text { the subsequent compilation of knowledge base on } \\
\text { product rules }\end{array}$ & $\begin{array}{l}\text { The complexity of the formation of knowledge } \\
\text { base with the account of more than five factors } \\
\text { about the object being studied }\end{array}$ \\
\hline
\end{tabular}

Ibrahim Mamdani $[10,11]$ is one of the first scientists who developed the concept of fuzzy control to manage complex processes, especially when there is no clear model for describing processes [10, 11]. Fuzzy management can be described as a means of controlling work with conditional sentences, which are called linguistic rules "IF-TO", rather than mathematical equations.

The derivation of the rule is called the conclusion and requires the definition of the membership function that characterizes this conclusion. This function defines the degree of truth of each sentence [14].

The various stages of a simple fuzzy logic control system are as follows:

- formation of the rules base of fuzzy output systems;

- phasification of input variables.

Each fuzzy system is implemented in the form of fuzzy rules (1), such as

$$
\begin{aligned}
& \text { Rule I : if A is } p_{1} \text { and Bis } q_{1} \text { then } Z \text { is } g_{1} \text {; } \\
& \text { Rule II :if A is } p_{2} \text { and Bis } q_{2} \text { then } Z \text { is } g_{2} \text {; }
\end{aligned}
$$

where $A$ and $B$ are variable parts of the condition, $Z$ is a part of the action variable, and $p_{i}$ and $q_{i}$ are fuzzy parameters characterized by membership functions. Some rules of the rules of control use measurements, which are usually valid numbers [23]:

$$
\mu_{g}(R)=\mu_{c 1}(R) * \mu_{c 2}(R),
$$

where "*" disjunction is the "max" function while using with the example of Mamdani.

- dephasing is a fuzzy result, which is the result of the conclusions, becomes a real value, which can be used as a control input. Since the desired output is an indeterminate result, the quantitative value of the control output is determined by dephasing $\mu_{g_{i}}(R)$. There are two general methods of defazification, which are the "center of gravity" and "average maximum" methods.

In artificial neural networks, the mathematical model simulates biological neural networks of the brain. A brain model connects many linear or nonlinear neuron models and processes information in a distributed manner. Since neural networks have training and selforganization capabilities, they can adapt to data changes and learn the characteristics of the input signal. Such networks can study the reflection between the input and output space and synthesize associative memory, which receives the corresponding output when it is presented with the input and is generalized while representing by new inputs [12]. Neural networks are used today in many industries, including recognition, identification, broadcasting, vision and control systems [13].

A neuron with an input vector with one n-element is shown in Fig. 1, where $p_{1}, p_{2}, p_{3}, p_{4}$ include separate elements and $\omega_{1}, \omega_{2}, \omega_{3}, \omega_{4}$ are the weights of the connections. An artificial neural network can be taught to perform a function by adjusting the weight values [13]. The block of the neuron has a displacement, which

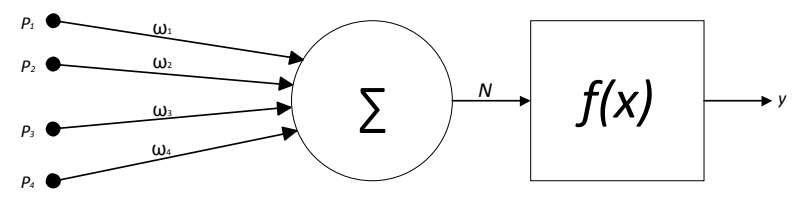

Fig. 1. Model of an artificial neuron

is summed up with the weight inputs to form a clean input. The output of a neuron is a weighted sum of input signals

$$
y=f\left(\sum_{i=1}^{n} p_{i} \bullet \omega_{1}+b\right) .
$$

The activation function of neurons is often a continuous and nonlinear function called a sigmoid function and is defined as 


$$
f(x)=1 /\left(1+e^{-a x}\right)
$$

where $e$ - constant and $0<f(\mathrm{x})<1$.

One of the most commonly used categories of artificial neural networks is called a direct network. This hierarchical structure consists of several layers without interconnections between the neurons in each layer, and signals come from the input layer to the output layer in one direction, as in Fig. 2.

The first layer of the neurons performs the procedure of phasation, bringing to fuzzy. As a result of this procedure, the values of the membership functions for the input variables are calculated. In order to ensure the maximum speed of the neuro-fuzzy data flow management system, it is proposed to use parametric, normal, unimodal and triangular membership functions. Given the different nature of the input and intermediate linguistic variables, the function of belonging is built separately for each variable.

The second layer performs the function of aggregation of the degrees of the truth of the conditions for each rule of the fuzzy output system in accordance with the operation of the T-norm, in which we use the operation min-conjuncture $[13,18,22]$. As a result of this procedure, the "cut off" levels are determined for the conditions of each of the rules. Those rules whose degrees of validity are different from zero are considered active and used for further calculations. The third layer of neurons forms at the output of the network a dephase value of the original value, which is the value of the level of pheromone which leaves behind an ant. As a method of dephasing in the Mamdani algorithm, a variant of the center of gravity method is used.

\section{Ant system of colonies}

In the articles [13], authors use ant-algorithms to find the route, and these algorithms are effective in solving the salesman's task.

The Ant Colony System (ACS) is a class of algorithms, the first term called the Ant System (AS), originally proposed by Dorigo et al. [13]. Although these ants are blind, they are able to find the shortest way from the food source to their nest, using a liquid substance called pheromone, which they release on the transit route.

The strategy of the Ant Colony tries to simulate the behavior of real ants with the addition of several artificial characteristics: visibility, memory and discrete time for the successful solution of many complex tasks such as the problem of a sales agent [14], the vehicle routing problem (VRP) [15], and the best route search [16]. Despite the fact that in recent years many changes have been made to the ACS algorithms, their fundamental mechanism of behavior, which is a positive feedback process demonstrated by an anonymised colony, remains unchanged. Anthropogenic algorithms have many applications, for example, for communication networks [17], electrical distribution networks [28]. There are different stages of the algorithm of the usual system of ants of colonies such as:

- a description of the schedule of tasks;

- artificial ants move between discrete states in discrete environments. Since the tasks solved by the algorithm of the automated control system (ACS) are often discrete, they can be represented by a graph with $N$ nodes and $R$ routes;

- initialization of distribution of ants;

- a number of ants are placed on nodes of origin;

- the number of ants is often determined based on trial and error and the number of nodes in the region.

The rule for the distribution of probabilities of ants

$$
P_{i j}^{k}=\left\{\begin{array}{c}
\frac{\left(\tau_{i j}\right)^{\alpha}\left(\eta_{i j}\right)^{\beta}}{\sum_{h \notin t a b u_{k}}\left(\tau_{i h}\right)^{\alpha}\left(\eta_{i h}\right)^{b}} j \notin t a b u_{k}, \\
0, \quad \text { otherwise }
\end{array}\right\} .
$$

The probabilistic transition of ants between nodes can also be specified as a rule of node transition. The probability of passing ant $k$ from a node $i$ to a node $j$ is given where $\tau_{i j}$ and $\eta_{i j}$ intensity of pheromones and the cost of the route between the nodes $i$ and $j$, respectively. The relative values $\tau i$ and $\eta i j$ are controlled by the parameters $\alpha$ and $\beta$, respectively. These are $t a b u_{k}$ unreachable routes (visited nodes) for the ant $k$.

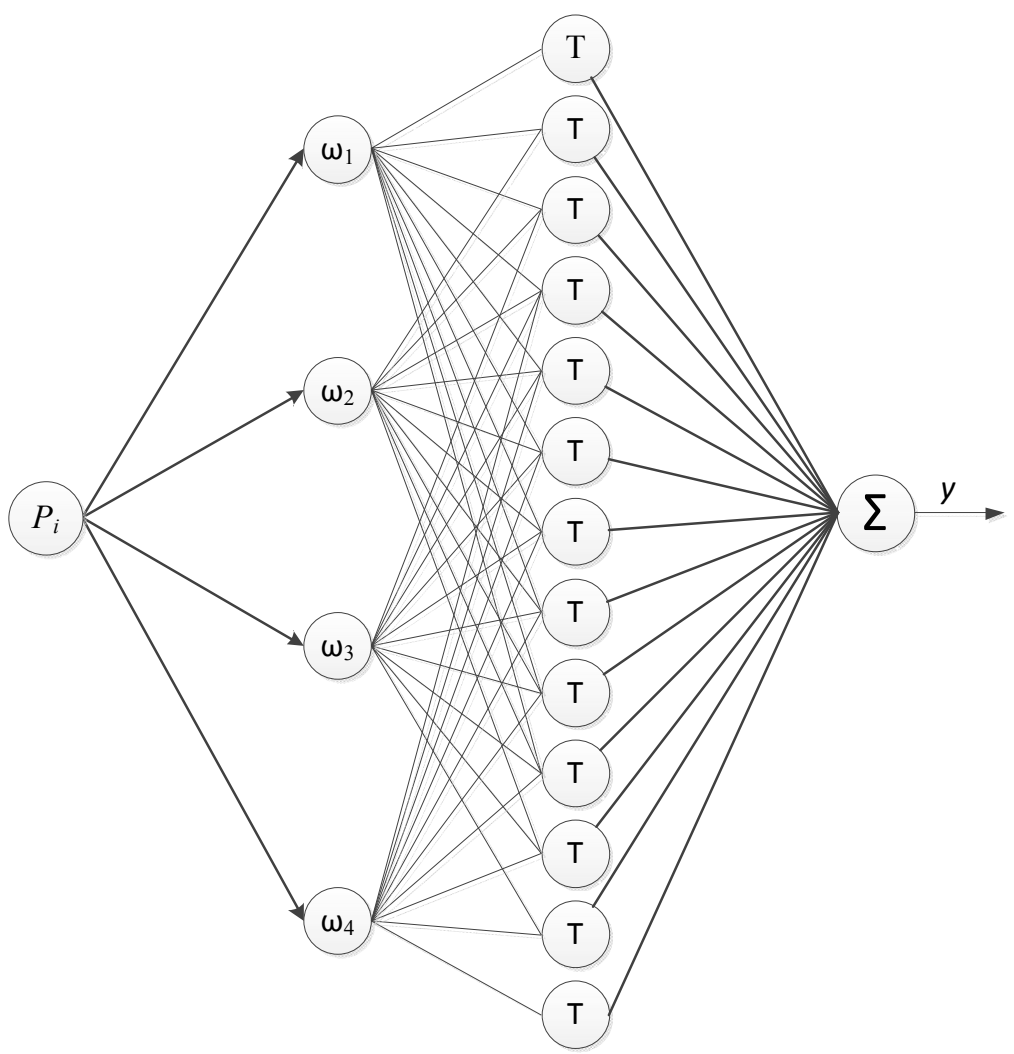

Fig. 2. Structure of a fuzzy neural network of one parameter for choosing the concentration of pheromone 


$$
\tau_{i j}^{n e w}=(1-p) \tau_{i j}^{o l d}+\sum_{k=1}^{m} \Delta \tau_{i j}^{k},
$$

where $0<\rho<1$ is a constant parameter called the evaporation of pheromones, and $m$ is the number of ants.

The amount of pheromone enclosed in the path between the nodes $i$ and $j$ ant $k$, is

$$
\Delta \tau_{i j}^{k}= \begin{cases}\frac{Q}{f_{k},} & \text { if it goes past the route }(i, j) \\ 0, & \text { otherwise },\end{cases}
$$

where $Q$ is a constant parameter and $f_{\mathrm{k}}$ is the value of the solution found from the $k$-th ant.
Stopping procedure - this procedure is completed by reaching a certain number of cycles or the maximum number of cycles between two improvements to the best global decisions.

\section{The conclusion from the article}

An analysis with taking into account the analysis of work on information processing [1-24] is considered the most expedient choice of methods of the theory of fuzzy sets for the processing of information evaluation factors, since its application allows us to develop a mechanism for processing information, taking into account the mutual influence both verbally and numerically described factors presented in different assessment scales.

\section{REFERENCES}

1. Pushpan, S., and Velusamy, B (2019). "Fuzzy-Based Dynamic Time Slot Allocation for Wireless Body Area Networks". Sensors, Vol. 19(9):2112, DOI: https://doi.org/10.3390/s19092112.

2. Hamzah, A, Shurman, M., Al-Jarrah, O. and Taqieddin, E(2019) "Energy-Efficient Fuzzy-Logic-Based Clustering Technique for Hierarchical Routing Protocols in Wireless Sensor Networks". Sensors, 19(3):561, DOI: https://doi.org/10.3390/s19030561.

3. Hu, X., Ma, L, Ding, Y., Xu, J., Li, Y. and Ma, S(2019). "Fuzzy Logic-Based Geographic Routing Protocol for Dynamic Wireless Sensor Networks". Sensors. 19(1):196, DOI: https://doi.org/10.3390/s19010196.

4. Shyshatskiy, A.V., Bashkirov, O.M. and Kostina, O.M (2015). "Development of integrated systems and data for Armed Forces", Arms and military equipment, No 1(5), pp. 35-40. available at: http://journals.uran.ua/index.php/24140651/issue/view/1\%285\%29\%202015 (last accessed november 25, 2018).

5. Leabi, S.K. and Abdalla, T.Y(2016). "Energy Efficient Routing Protocol for Maximizing Lifetime in Wireless Sensor Networks using Fuzzy Logic and Immune System". International Journal of Advanced Computer Science and Applications, Vol. 7, No. 10, 2016, pp: 95-101.

6. Zhuk, O.G., Shyshatskiy, A.V., Zhuk, P.V. and Zhyvotovskyi, R.M (2017). "Methodological substances of management of the radio-resource managing systems of military radio communication", Information Processing Systems, Vol. 5(151), pp. 16-25. https://doi.org/10.30748/soi.2017.151.02.

7. Romanenko,I and Shyshatskyi, A (2017). "Analysis of modern condition of military radiocommunication system", Advanced Information Systems, Vol. 1, No. 1, pp. 28-33 DOI: https://doi.org/10.20998/2522-9052.2017.1.05.

8. Oubaha, J. and Ez-zahout, A(2018). "Performance Measure and Analysis of MPLS and conventional IP network through VoIP: Effect in Video and Audio transmission". Journal of Networking Technology, Volume 9, No. 2, pp. 56-65.

9. Sankar, S. and Srinivasan, P(2018). "Fuzzy Logic Based Energy Aware Routing Protocol for Internet of Things". International Journal of Intelligent Systems and Applications (IJISA), Vol.10, No.10, pages: 11-19, 2018, DOI: 10.5815/ijisa.2018.10.02.

10. Dhand, G. D. and Kumar, R(2019) "Devashish Ghildiyal, Rachna Jain. QoS and Fuzzy Logic Based Routing Protocol for CRN". International Journal of Computer Networks and Applications (IJCNA), Vol. 6, Iss. 2, pp: 31 - 38, DOI: 10.22247/ijcna/2019/49618.

11. Jiang, J., Liu, Y., Song, F., Du, R. and Huang, M(2015) "The Routing Algorithm Based on Fuzzy Logic Applied to the Individual Physiological Monitoring Wearable Wireless Sensor Network". Hindawi Publishing Corporation Journal of Electrical and Computer Engineering, Vol. 2015, Article ID 546425, 7 pages, DOI: 10.1155/2015/546425.

12. Fahad, T.O. and Ali, A.A(2019). "Compressed fuzzy logic based multi-criteria AODV routing in VANET environment". International Journal of Electrical and Computer Engineering (IJECE), Vol. 9, No. 1, pp: 397-401, ISSN: 2088-8708, DOI: 10.11591/ijece.v9i1.pp397-401.

13. Garga, M.K., Singhb, N. and Verma, P(2018). "Fuzzy rule-based approach for design and analysis of a Trust-based Secure Routing Protocol for MANETs". International Conference on Computational Intelligence and Data Science (ICCIDS 2018), Procedia Computer Science 132 (2018), pp: 653-658.

14. Romanyuk, V., Sova, O., Romanyuk, A., Salnyk, S(2016). "The MANET`s Hierarchical Control System Using Fuzzy Logic", TCSET'2016, February 23 - 26, 2016, Lviv-Slavske, Ukraine.

15. Romanyuk, V., Sova, O., Aleksenko, V.P. and Symonenko, O.A(2017). " Methodology for the construction of fuzzy knowledge bases of intelligent control systems for nodes of tactical mobile radio networks". Collection of scientific works of MITI, No 3, pp: 135-148.

16. Strela,T. and Romanyuk, V. (2018). "Clustering method in wireless sensor networks using fuzzy logic". Collection of scientific works of MITI, No. 5, pp: 210-212.

17. Salehinejad, H. and Talebi, S(2010) "Dynamic Fuzzy Logic-Ant Colony System-Based Route Selection System, Hindawi Publishing Corporation". Applied Computational Intelligence and Soft Computing, Vol. 2010, Article ID 428270, 13 pages, DOI:10.1155/2010/428270.

18. Shtovba, S.D(2005). "Ant Algorithms: Theory and Applications". Programming and Computer Software, Vol. 31, No. 4, pp: 167-178, Vol. 31, No. 4.

19. Asokan, R., Natarajan, A.M.,and Venkatesh, C. “Ant Based Dynamic Source Routing Protocol to Support Multiple Quality of Service (QoS) Metrics in Mobile Ad Hoc Networks". International Journal of Computer Science and Security, Vol. 2, Iss. 3, pp: 48-65. 
20. Zungeru, A.M., Seng, K.P., Ang, L.M. and Chia, W.C(2013). "Energy Efficiency Performance Improvements for Ant-Based Routing Algorithm in Wireless Sensor Networks". Journal of Sensors, Vol. 2013, Hindawi Publishing Corporation, Article ID 759654, 17 pages, DOI: 10.1155/2013/759654.

21. Li, Y.Q., Wang, Q.W., Fan, Q.G. and Chen, B.S(2018). "Reliable Ant Colony Routing Algorithm for Dual-Channel Mobile Ad Hoc Networks". Hindawi Wireless Communications and Mobile Computing, Vol. 2018, Article ID 4746020, 10 pages, DOI: $10.1155 / 2018 / 4746020$.

22. Joseph I.C(2014). "Cognitive Ant Colony Optimization: A New Framework in Swarm Intelligence. School of Computing", Science and Engineering College of Science and Technology University of Salford, Manchester, UK, 143 pages.

23. Rothstein, O.P., Shtovba SD and Kozachko, O.M(2007)."Modeling and optimization of reliability of multidimensional algorithmic processes ", Monograph, UNIVERSUM-Vinnytsia.

24. Nalapko, O.L. and Shyshatskyi, A.V(2018) "Analysis of technical characteristics of the network with possibility to selforganization". National Technical University "Kharkiv Polytechnic Institute", Scientific and Technical Journal "Advanced Information Systems", pp. 78-86. DOI: https://doi.org/10.20998/2522-9052.2018.4.14

Рецензент: д-р техн. наук, проф. С. І. Приходько, Український державний університет залізничного транспорту, Харків Надійшла (received) 19.04.2019

Прийнята до друку (accepted for publication) 29.05.2019

\section{Аналіз математичного апарату для управління канальними та мережевими ресурсами} систем військового радіозв'язку

О. Л. Налапко, Р. В. Пікуль, П. В. Жук, А. В. Шишацький

Досвід проведення Операції Об’єднаних Сил (антитерористичної операції) на території Донецької та Луганської областей свідчить, що існуючий порядок управління канальними та мережевими ресурсами систем військового радіозв’язку не задовольняє сучасним вимогам, що висуваються до них. Вибір маршруту в мережах спеціального призначення 3 можливістю до самоорганізації на основі конкретних параметрів $є$ головною проблемою для управління канальними та мережевими ресурсами мереж спеціального призначення, а також складною задачею сходження мережі. В зазначеній статті авторами проведено аналіз існуючого математичного апарату для управління канальними та мережевими ресурсами систем військового радіозв'язку. Під час проведення дослідження авторами статті були використані класичні методи наукового пізнання, а саме методи аналізу та синтезу, основні положення теорії зв'язку, методи моделювання мереж зв'язку, теорії штучного інтелекту та інш. Встановлено, що існуючі методи управління канальними та мережевими ресурсами систем військового радіозв'язку враховують тільки окремі чинники, що впливають на якість використання канальних та мережевих ресурсів систем військового радіозв'язку. Тому найбільш доцільно проводити вибір маршруту передачі інформації за багатьма параметрами на основі нечіткої логіки та модифікованого методу системи мурашиних колоній, за допомогою якого відбувається пошук та підтримання маршруту проходження пакету між двома точками, між вузлом з якого надсилається IP пакет і вузлом призначення. Для пошуку маршруту необхідно враховувати наступні параметри: енергетична складова, швидкість передачі даних, час затримки IP пакету від вузла, що надсилає пакет до вузла призначення та надійність доставки IP пакету. Зазначені параметри доцільно врахувати при створенні математичних моделей, методів та методик управління канальними та мережевими ресурсами систем військового радіозв'язку.

Ключов і слов а: система радіозв'язку, радіоресурс, канальні та мережеві ресурси, топологія мережі, мережа зв'язку, маршрутизація.

\section{Анализ математического аппарата для управления канальными и сетевыми ресурсами систем военной радиосвязи}

\section{А. Л. Налапко, Р. В. Пикуль, П. В. Жук, А. В. Шишацкий}

Опыт проведения Операции Объединенных Сил (антитеррористической операции) на территории Донецкой и Луганской областей свидетельствует, что существующий порядок управления канальными и сетевыми ресурсами систем военной радиосвязи не удовлетворяет современным требованиям, предъявляемым к ним. Выбор маршрута в сетях специального назначения с возможностью к самоорганизации на основе конкретных параметров является главной проблемой для управления канальными и сетевыми ресурсами сетей специального назначения, а также сложной задачей схождения сети. В указанной статье авторами проведён анализ существующего математического аппарата для управления канальными и сетевыми ресурсами систем военной радиосвязи. Во время проведения исследования авторами статьи были использованы классические методы научного познания, а именно методы анализа и синтеза, основные положения теории связи, методы моделирования сетей связи, теории искусственного интеллекта и др. Установлено, что существующие методы управления канальными и сетевыми ресурсами систем военной радиосвязи учитывают только отдельные факторы, влияющие на качество использования канальных и сетевых ресурсов систем военной радиосвязи. Поэтому наиболее целесообразно проводить выбор маршрута передачи информации по многим параметрам на основе нечеткой логики и модифицированного метода системы муравьиных колоний, с помощью которого происходит поиск и поддержание маршрута следования пакета между двумя точками, между узлом с которого направляется IP пакет и узлом назначения. Для поиска маршрута необходимо учитывать следующие параметры: энергетическая составляющая, скорость передачи данных, время задержки IP пакета от узла который направляет пакет до узла назначения и надежность доставки IP-пакета. Указанные параметры целесообразно учесть при создании математических моделей, методов и методик управления канальными и сетевыми ресурсами систем военного радиосвязи.

Ключевые слов а: система радиосвязи, радиоресурс, канальные и сетевые ресурсы, топология сети, сеть связи, маршрутизация. 